\title{
Artificial nest predation rates vary depending on visibility in the eastern Brazilian Amazon
}

\author{
Fernanda MICHALSKI ${ }^{1 *}$, Darren NORRIS ${ }^{2}$ \\ 1 Universidade Federal do Amapá, Laboratório de Ecologia e Conservação de Vertebrados, Rod. Juscelino Kubitschek, km 02, Macapá, AP, 68902-280, Brazil; \\ 2 Instituto Nacional de Pesquisas da Amazônia, Coordenação de Biodiversidade, C.P. 478, Manaus, AM, 69060-001, Brazil. E-mail: dnorris75@gmail.com \\ * Corresponding author: fmichalski@procarnivoros.org.br
}

\section{ABSTRACT}

Observational and experimental studies have shown that increased concealment of bird nests reduces nest predation rates. The objective of the present study was to evaluate differences in predation rates between two experimental manipulations of artificial ground nests (i.e., clearing an area around the artificial nest or leaving it as natural as possible), and test whether environmental variables also affected nest predation in an undisturbed area of Amazonian forest in eastern Brazil. A generalized linear model was used to examine the influence of five variables (manipulation type, perpendicular distance from the main trail, total basal area of trees surrounding the nest site, understorey density, and liana quantity) on nest predation rates. Model results, showed that manipulation type was the only variable that significantly affected nest predation rates. Thus, to avoid systematic biases, the influence of nest site manipulation must be taken into consideration when conducting experiments with artificial nests.

KEYWORDS: Experimental manipulation, potential biases, quail egg.

\section{Taxas de predação em ninhos artificiais variam dependendo da visibilidade na Amazônia Oriental Brasileira}

\begin{abstract}
RESUMO
Estudos de observação e experimentais demonstraram que ninhos de aves menos visíveis apresentam taxas de predação reduzidas. O objetivo do presente estudo foi avaliar diferenças nas taxas de predação entre duas manipulações experimentais de ninhos artificiais no chão (i.e., limpando uma área em torno do ninho artificial ou deixando o mais natural possível), e testar se variáveis ambientais também poderiam afetar as taxas de predação em uma área intacta de floresta amazônica no leste do Brasil. Um modelo generalizado linear foi utilizado para examinar a influência de cinco variáveis (tipo de manipulação, distância perpendicular da trilha principal, área basal total das árvores em volta do local do ninho, densidade de sub-bosque, e quantidade de lianas) sobre as taxas de predação de ninhos. Os resultados do modelo demonstraram que tipo de manipulação foi a única variável que afetou significativamente as taxas de predação de ninhos. Assim, para evitar vieses sistemáticos, a influência da manipulação do local dos ninhos deve ser levada em consideração na realização de experimentos com ninhos artificiais.
\end{abstract}

PALAVRAS-CHAVE: Manipulaçáo experimental, potenciais vieses, ovo de codorna. 
Nest predation is not only the primary cause of reproductive failure in birds, but is also a major factor that can shape the evolution of avian life histories (Ricklefs 1969; Martin 2002), and drive bird species population dynamics (Clark and Martin 2007). Nest site selection and nest defense are strategies used by birds to reduce nest predation (Martin 1993; Götmark et al. 1995; Boulton et al. 2003). Indeed, according to the nest-concealment hypothesis, nests that are more concealed are less prone to be predated (Ricklefs 1969; Filliater et al. 1994; Weidinger 2002).

Nest predation may be also determined by the community of potential predators (Weatherhead and Blouin-Demers 2004). However, the impact of any community of potential nest predators also depends on different nest-site characteristics in terms of site selection, concealment and associated environmental variables (Fortaine and Martin 2006; Colombelli-Negrel and Kleindorfer 2009). For example, cover above and below the nest can be important predictors of avian (Remes 2005) and snake predations (Kleindorfer $e t$ al. 2003), respectively. Therefore, a nest site can be highly susceptible to some predators, but exhibit low predation risk for other predators. The complexity of these interactions means that experimental manipulations are frequently used to understand the ecological mechanisms driving nest predation rates (Martin and Geuple 1993; Major and Kendal 1996; Fontaine and Martin 2006).

The experimental manipulation of nest sites and egg concealment has been widely applied to examine nest predation patterns, with studies focusing on the effects of habitat fragmentation (Spanhove et al. 2009), anthropogenic disturbances (Lopez-Flores et al. 2009), and habitat variation (Noske et al. 2008). Yet, the potential bias introduced by the experimental manipulation of nest sites that is commonly applied in nest predation studies for example the use of track-boards (DeGraaf and Angelstam 1993; Pedersen et al. 2009) has rarely been assessed, with studies mainly focusing on comparisons between egg types (Bayne et al. 1997; Maier and Degraaf 2001; Alvarez and Galetti 2007). Our objective was to evaluate differences in predation rates between experimental manipulations of artificial ground nests that are commonly applied in nest predation studies. We predicted higher predation rates in artificial nests established on cleared areas, as removal of leaves and debris results in increased egg exposure, and therefore increased vulnerability to predators. This prediction was tested by examining differences in predation rates of plasticine and quail eggs between two different experimental manipulations (i.e., clearing an area around the artificial nest and leaving it as natural as possible).

This study was conducted in the Jari Ecological Station (known locally as ESEC Jari), which has an area of 227,126 ha and is located on the border between the Brazilian States of Pará and Amapá $\left(00^{\circ} 51^{\prime} S\right.$ and $053^{\circ} 24^{\prime} \mathrm{W}$, Figure 1). The annual precipitation in the area is $2,115 \mathrm{~mm}$, ranging from $290 \mathrm{~mm}$ in May to $41 \mathrm{~mm}$ in October, with a distinct dry season between September and November (Correa et al. 1989). In September 2011, we set 76 artificial ground nests along 38 transects ( 19 with cleared nest sites and 19 uncleared) separated by at least $50 \mathrm{~m}$. The freshly cut transects were, established perpendicular to a pre-existing trail in the Jari Ecological Station (IBAMA/SISBIO permit n ${ }^{\circ} 31054$, Figure 1). Two artificial nests were placed on each transect, at $50 \mathrm{~m}$ and $100 \mathrm{~m}$ from the trail. Each nest consisted of one quail (Coturnix coturnix) egg measuring ca. $3.5 \times 2.5 \mathrm{~cm}$ and one plasticine egg that was moulded to be a similar shape and size to the quail egg. Both eggs were placed directly on the ground next to each other. From the total of artificial nests, half $(n=38)$ were placed on the ground after a $1 \mathrm{~m}^{2}$ area had been manually (using latex gloves to avoid direct transfer of human scent) cleared of any debris or vegetation, thereby exposing bare soil. The other half $(\mathrm{n}=38)$ of nest sites were set without disturbing the existing ground cover (i.e. uncleared). Transects and nest sites were marked with flagging tapes. All eggs were checked and removed on the third day ( -72 hours). Although artificial nest experiments usually run over periods of 7-10 days (Noske et al. 2008; Alvarez and Galetti 2007; Pedersen et al. 2009) due to logistical constrains we could not leave the eggs for more than 72 hours in the field. To reduce interference caused by the transfer of human scent to the eggs, latex gloves and rubber boots were used when handling and placing eggs in the field. Predation was recorded to have occurred if one or both eggs had been removed or marked in some way (e.g., obvious claw, beak, or tooth marks in the plasticine egg). In each nest site we measured four environmental variables (i) perpendicular distance from the main trail (at fixed distances of $50 \mathrm{~m}$ and $100 \mathrm{~m}$ ), (ii) total basal area of trees $\geq 10 \mathrm{~cm} \mathrm{DBH}$ (diameter at breast height) within a $5 \mathrm{~m}$ radius from the centre

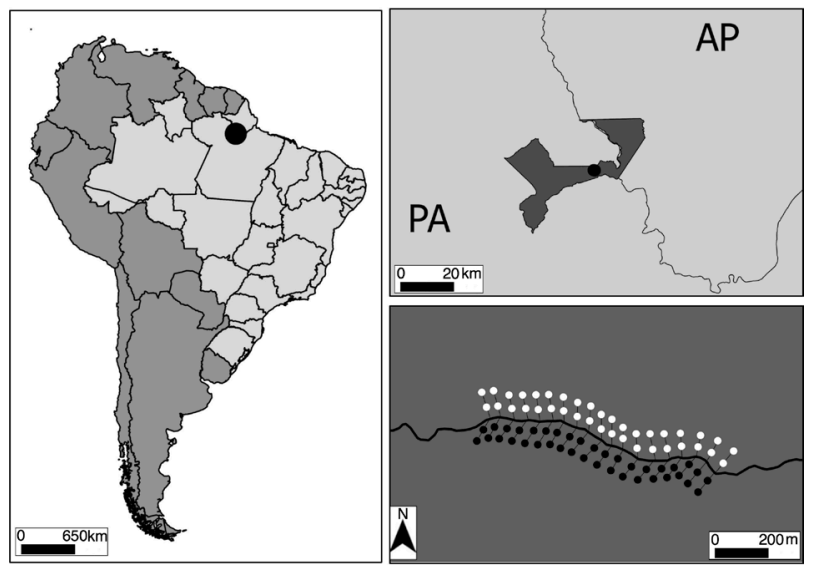

Figure 1. Location of the study region in the Jari Ecological Station, Pará state, Brazil, showing the 76 artificial nests monitored (38 open and 38 solid circles represent cleared and uncleared manipulation, respectively). 
of the nest (expressed in $\mathrm{m}^{2}$ and obtained using the formula: basal area $\left.=\pi^{*}(\mathrm{DBH} / 200)^{2}\right)$, and (iii) understorey density measured using a $2.5 \mathrm{~m}$ graduated pole held vertically by one observer and examined from $5 \mathrm{~m}$ away by another (Barlow $e t$ al. 2002). A total of 2 readings were recorded at each nest site corresponding to the number of $10 \mathrm{~cm}$ pole sections (range: $0-25)$ that were clearly visible. Finally, we measured the fourth environmental variable: (iv) liana quantity within a $5 \mathrm{~m}$ radius from the centre of the nest, based on a five rank scale (ranging from 0 with total absence of lianas, to 4 with trees covered with large quantity of lianas). Areas with an elevated density of lianas in the canopy are generally chosen by ring-tailed coati (Nasua nasua) females for nest sites (Olifiers et al. 2009; Hirsch 2011), a species recognized as a potential predator of bird nests (Alvarez and Galetti 2007). All analyses were performed in R 2.15.1 (R Development Core Team 2012). To assess the predation rates on artificial nests we examined the effects of (i) manipulation type (e.g. categorical factor, clear or uncleared), (ii) perpendicular distance from the main trail (e.g. categorical factor, $50 \mathrm{~m}$ and $100 \mathrm{~m}$ ), (iii) total basal area of trees $\geq 10 \mathrm{~cm} \mathrm{BDH}$, (iv) understorey density, and (v) liana rank scale as predicting variables. We controlled for high levels of inter-dependence between variables by examining correlations (Pearson product-moment correlations between numeric variables, polyserial correlations between numeric and ordinal variables, and polychoric correlations between ordinal variables (Fox 2010)) and retaining only weakly correlated variables $|R|<0.60$. We used generalized linear models (GLMs) with a binomial (logit) error structure to investigate predictors of probability of egg predation (yes or no) at each artificial nest as a binary response variable and all other variables as predictors.

Of the 76 artificial nests 21 (28\%) were predated within 72 hours. As we predicted, artificial nests that were less concealed (cleared sites) were more predated $(n=13,36 \%)$ when compared with more concealed nests $(\mathrm{n}=8,22 \%)$. Our results clearly agree with the nest-concealment hypothesis, that nest concealment is a good strategy to reduce predation risks (Ricklefs 1969; Filliater et al. 1994; Boulton et al. 2003). Considering our relatively short experimental period, our predation rates were within the range of values reported by other studies that showed $70 \%$ nest depredation rates over 9 days (Noske et al. 2008), and 94\% nest predation over 15 days (Lopez-Flores et al. 2009). This suggests that leaving our experiment for longer periods would also show a similar predation rate to previous studies and that differences in predation patterns between cleared and uncleared nests could be even stronger. The GLM results showed that type of experimental manipulation was the only variable that significantly influenced predation rates, with uncleared nests (slope $\pm \mathrm{SE}=-1.549 \pm 0.796, P<0.05$ ) having significantly lower predation rates compared with cleared nest sites (Table
Table 1. Generalized Linear Model results (slope coefficients with associated \pm SE in parentheses) of predictors of the predation on 76 artificial nests in a continuous undisturbed forest in the eastern Brazilian Amazon.

\begin{tabular}{ccc}
\hline Variable & Estimate $( \pm \mathrm{SE})$ & P value \\
\hline $\begin{array}{c}\text { Experimental manipulation } \\
\text { Uncleared }\end{array}$ & $-1.549(0.796)$ & 0.045 \\
$\begin{array}{c}\text { Perpendicular distance } \\
\text { 100m }\end{array}$ & $0.612(0.567)$ & 0.281 \\
Total basal area & $1.910(1.747)$ & 0.275 \\
Understorey density & $1.006(0.842)$ & 0.233 \\
Liana & & \\
Low & $-0.618(0.671)$ & 0.357 \\
Moderate & $-1.470(0.954)$ & 0.123 \\
High & $-15.552(32.299)$ & 0.993 \\
\hline
\end{tabular}

1). The GLM model predictions followed the pattern of observed values with nest predation estimates $($ mean $\pm \mathrm{SE}$ ) of $37 \% \pm 12 \%$ and $18 \% \pm 9 \%$ for cleared and uncleared nests, respectively. This finding was expected as nest concealment is known to shape the evolution of avian life histories (Ricklefs 1969). The plasticine egg was removed or damaged from $15(71 \%)$ of the 21 predated nests. Increased predation on plasticine eggs compared with quail eggs has been well documented in previous studies with one of the proposed explanations being that quail eggs may be too hard for some small mammals to penetrate the shell, but the same species may leave marks on plasticine eggs (Bayne et al. 1997; Maier and Degraaf 2001; Alvarez and Galetti 2007). Indeed, from the nests that had plasticine eggs left with marks, we could identify that small mammals were responsible for the majority of the predation events $(n=5)$, followed by birds $(n=4)$.

We found a clear pattern of increased predation rates at the more exposed ("cleared") artificial nests. Although conducted over a short period our study highlights that the types of manipulation (i.e., degree of nest concealment) adopted during nest predation experiments (Weidinger 2002; Colombelli-Negrel and Kleindorfer 2009) can affect the results and should be described and considered carefully so that robust inferences can be generated. This is likely to be particularly true for studies that use track-boards (DeGraaf and Angelstam 1993; Pedersen et al. 2009) and/or clear areas to identify tracks of elusive and cryptic vertebrates (Cain et al. 2003; Meckstroth et al. 2005; Norris et al. 2008).

\section{ACKNOWLEDGEMENTS}

This study was funded by Conservation International Brazil and the Universidade Federal do Amapá (UNIFAP). The Instituto Chico Mendes de Conservação da Biodiversidade and UNIFAP provided logistical support. We are deeply indebted to students from the Post-Graduation Programme in Tropical Biodiversity ("Programa de Pós-Graduaçâo em Biodiversidade Tropical” - PPGBIO) for field assistance. This 
article resulted from the PPGBIO course in field ecology conducted in 2011.

\section{REFERENCES}

Alvarez, A.D.; Galetti, M. 2007. Predação de ninhos artificiais em uma ilha na Mata Atlântica: testando o local e o tipo de ovo. Revista Brasileira de Zoologia, 24: 1011-1016.

Bayne, E.M.; Hobson, K.A.; Fargey, P. 1997. Predation on artificial nests in relation to forest type: contrasting the use of quail and plasticine eggs. Ecography, 20: 233-239.

Barlow, J.; Haugaasen, T.; Peres, C.A. 2002. Effects of ground fires on understorey bird assemblages in Amazonian forests. Biological Conservation, 105: 157-169.

Boulton, R.L.; Cassey, P.; Schipper, C.; Clarke, M.F. 2003. Nest site selection by yellow-faced honeyeaters Lichenostomus chrysops. Journal of Avian Biology, 34: 267-274.

Cain, J.W.; Morrison, M.L.; Bombay, H.L. 2003. Predator activity and nest success of Willow Flycatchers and Yellow Warblers. The Journal of Wildlife Management, 67: 600-610.

Clark, M.E.; Martin, T.E. 2007. Modelling tradeoffs in avian life history traits and consequences for population growth. Ecological Modelling, 209: 110-120.

Colombelli-Negrel, D.; Kleindorfer, S. 2009. Nest height, nest concealment, and predator type predict nest predation in superb fairy-wrens (Malurus cyaneus). Ecological Research, 24: 921-928.

Correa, J.L.L.; Jacomine, P.K.T.; Santos, R.D. 1989. Solos do Jari - Levantamento de reconhecimento de média intensidade dos solos sob floresta cultivada na área da Companhia Florestal Monte Dourado PA. Cia. Florestal Monte Dourado, Monte Dourado, PA, 2 volumes.

DeGraaf, R.M.; Angelstam, P. 1993. Effects of timber size-class on predation of artificial nests in extensive forest. Forest Ecology and Management, 61: 127-136.

Filliater, T.S.; Breitwisch, R.; Nealen, P.M. 1994. Predation on Northern Cardinal nests: does choice of nest site matter? The Condor, 96: 761-768.

Fontaine, J.J.; Martin, T.E. 2006. Habitat selection responses of parents to offspring predation risk: an experimental test. The American Naturalist, 168: 811-818.

Fox, J. 2010. Polycor: Polychoric and Polyserial Correlations. R package version 0.7-8. http://CRAN.R-project.org/ package $=$ polycor.

Hirsch, B.T. 2011. Within-group spatial position in ring-tailed coatis: balancing predation, feeding competition, and social competition. Behavioral Ecology and Sociobiology, 65: 391-399.

Götmark, F; Blomqvist, D.; Johansson, O.C.; Bergkvist, J. 1995. Nest site selection: a trade-off between concealment and view of the surroundings?. Journal of Avian Biology, 26: 305-312.

Kleindorfer, S.; Fessl, B.; Hoi, H. 2003. The role of nest site cover for parental nest defence and fledging success in two Acrocephalus warbles. Avian Science, 3: 21-29.
Lopez-Flores, V.; MacGregor-Fors, I.; Schondube, J.E. 2009. Artificial nest predation along a Neotropical urban gradient. Landscape and Urban Planning, 92: 90-95.

Maier, T.J.; Degraaf, R.M. 2001. Differences in depredation by small predators limit the use of plasticine and zebra finch eggs in artificial-nest studies. The Condor, 103: 180-183.

Major, R.E.; Kendal, C.E. 1996. The contribution of artificial nest experiments to understanding avian reproductive success: a review of methods and conclusions. Ibis, 138: 298-307.

Martin, T.E. 1993. Nest predation and nest sites: new perspectives and old patterns. Bioscience, 43: 523-532.

Martin, T.E. 2002. A new view of avian life-history evolution tested on an incubation paradox. Proceedings of the Royal Society B: Biological Sciences, 269: 309-316.

Martin, T.E.; Geupel, G.R. 1993. Nest-Monitoring Plots: Methods for Locating Nests and Monitoring Success. Journal of Field Ornithology, 64: 507-519.

Meckstroth, A.M.; Miles, A.K. 2005. Predator removal and nesting waterbird at San Francisco Bay, California. Waterbirds, 28: 250-255.

Norris, D.; Peres, C.A.; Michalski, F.; Hinchsliffe, K. 2008. Terrestrial mammal responses to edges in Amazonian forest patches: a study based on track stations. Mammalia, 72: 15-23.

Noske, R.A.; Fischer, S.; Brook, B.W. 2008. Artificial nest predation rates vary among habitats in the Australian monsoon tropics. Ecological Research, 23: 519-527.

Olifiers, N.; Bianchi, R.C.; Mourão, G.M.; Gompper, M.E. 2009. Construction of aboreal nests by brown-nosed coatis, Nasua nasua (Carnivora: Procyonidae) in the Brazilian Pantanal. Zoologia, 26: 571-574.

Pedersen, A.Ø.; Yoccoz, N.G.; Ims, R.A. 2009. Spatial and temporal patterns of artificial nest predation in mountain birch forests fragmented by spruce plantations. European Journal of Wildlife Research, 55: 371-384.

R Development Core Team. 2012. R: a language and environment for statistical computing. R Foundation for Statistical Computing, Vienna, Austria. ISBN 3- 900051-07-0. http://www.R-project. org.

Remes, V. 2005. Birds and rodents destroy different nests: a study of blackcap Sylvia atricapilla using the removal of nest concealment. Ibis, 147: 213-216.

Ricklefs, R.E. 1969. The nesting cycle of songbirds in tropical and temperate regions. Living Bird, 8: 165-175.

Spanhove, T.; Lehouck, V.; Boets, P.; Lens, L. 2009. Forest fragmentation relaxes natural nest predation in an Afromontane forest. Animal Conservation, 12: 267-275.

Weatherhead, P.J.; Blouin-Demers, G. 2004. Understanding avian nest predation: why ornithologists should study snakes. Journal of Avian Biology, 35: 185-190.

Weidinger, K. 2002. Interactive effects of concealment, parental behaviour and predators on the survival of open passerine nests. Journal of Animal Ecology, 71: 424-437.

Recebido em 16/05/2013

Aceito em 26/08/2013 